\title{
Discussion Paper No. 13-024 \\ Did Fukushima Matter? \\ Empirical Evidence of the Demand for Climate Protection in Germany
}

Carlo Gallier, Andreas Löschel, and Bodo Sturm

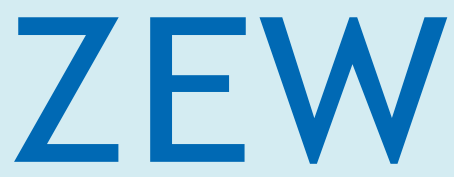

Zentrum für Europäische Wirtschaftsforschung $\mathrm{GmbH}$

Centre for European

Economic Research 
Discussion Paper No. 13-024

\title{
Did Fukushima Matter? Empirical Evidence of the Demand for Climate Protection in Germany
}

\author{
Carlo Gallier, Andreas Löschel, \\ and Bodo Sturm
}

Download this ZEW Discussion Paper from our ftp server:

http://ftp.zew.de/pub/zew-docs/dp/dp13024.pdf

Die Discussion Papers dienen einer möglichst schnellen Verbreitung von neueren Forschungsarbeiten des ZEW. Die Beiträge liegen in alleiniger Verantwortung der Autoren und stellen nicht notwendigerweise die Meinung des ZEW dar.

Discussion Papers are intended to make results of ZEW research promptly available to other economists in order to encourage discussion and suggestions for revisions. The authors are solely responsible for the contents which do not necessarily represent the opinion of the ZEW. 


\section{Non-technical summary}

This paper investigates the extent to which the Fukushima Daiichi nuclear disaster of March 2011 has had an impact on the private demand for climate protection in Germany. On March 11, 2011 the Tohoku earthquake and subsequent tsunami hit Japan and the Fukushima Daiichi nuclear power plant. Within a few days, the nuclear power plant went in to melt down and released radioactive material into both the air and the ocean. The Fukushima Daiichi nuclear disaster sparked a worldwide discussion about the use of nuclear energy and the security of nuclear power plants. However, despite having major humanitarian and environmental consequences, can the Fukushima Daiichi nuclear disaster impact the private demand for climate protection in Germany?

Immediately following the disaster a debate about the use of nuclear power started in Germany. As a consequence of the disaster, the German government decreed an out phasing of nuclear power plants. This significant change in German energy policy will ceteris-paribus result in an increase in national $\mathrm{CO}_{2}$ emissions as Germany abstains from one carbon free technology. Therefore, in order to ensure the same national $\mathrm{CO}_{2}$ emissions the change in German energy policy implies a higher private willingness to contribute to climate protection. Another argument is that climate change is a potential driver of extreme weather events which could become a factor causing future nuclear disasters. Therefore, the increased awareness of nuclear disasters, as a direct result of the events in Fukushima, could also influence the willingness to contribute to climate protection.

Data for the demand for climate protection in this paper are taken from two framed field experiments conducted in Mannheim, Germany, before and after the disaster. Within both experiments subjects had the opportunity to invest in climate protection by purchasing and withdrawing permits from the European Emission Trading Scheme (EU ETS) using their own disposable income.

We find that the individual demand for climate protection among a sample of the residential population of Mannheim has changed significantly between March 2010 and December 2011. The demand for climate protection identified in the experiment following the nuclear disaster is significantly higher than in the experiment before the disaster. We conclude that individuals who wish to guarantee a certain level of national climate protection or who are aware of potential consequences of climate change for extreme weather events increased their private willingness to contribute to climate protection. 


\section{Das Wichtigste in Kürze}

Wir untersuchen, ob die Nuklearkatastrophe von Fukushima im März 2011 einen Einfluss auf die private Nachfrage nach Klimaschutz in Deutschland hatte. Am 11. März 2011 ereignete sich das Tohoku-Erdbeben und löste einen Tsunami aus. Der Tsunami traf das Kernkraftwerk Fukushima Daiichi. In wenigen Tagen kam es zu einer Kernschmelze, wobei radioaktives Material freigesetzt wurde. Aber warum sollte die Nuklearkatastrophe von Fukushima einen Einfluss auf die reale Nachfrage nach Klimaschutz in Deutschland haben?

Die Nuklearkatastrophe von Fukushima löste in Deutschland eine Debatte über die Nutzung von Kernenergie aus. Als Reaktion auf die Nuklearkatastrophe wurde unmittelbar nach den Ereignissen in Japan der Atomausstieg beschlossen. Dieser Wandel in der deutschen Energiepolitik lässt unter sonst gleichen Bedingungen die nationalen $\mathrm{CO}_{2}$-Emissionen bei gegebenen Kosten steigen, da Deutschland freiwillig auf eine kohlenstofffreie Technologie verzichtet. Mit anderen Worten: Es müssen höhere Kosten getragen werden, um ein gegebenes $\mathrm{CO}_{2}$-Emissionsniveau $\mathrm{zu}$ erreichen. Diese Kehrtwende in der deutschen Energiepolitik könnte daher mit einer höheren privaten Nachfrage nach Klimaschutz einhergehen - wenn die Bevölkerung antizipiert, dass Klimaschutz in Zukunft mit höheren Kosten verbunden sein wird. Ein weiteres Argument ist, dass der Klimawandel die Wahrscheinlichkeit von Extremwettereignissen und damit auch Nuklearkatastrophen erhöht. Aufgrund der Ereignisse in Fukushima könnte eine gestiegene Besorgnis über mögliche nukleare Katastrophen auch die private Nachfrage nach Klimaschutz erhöhen.

Die Daten zur privaten Nachfrage nach Klimaschutz stammen aus zwei Experimenten, die in Mannheim durchgeführt wurden. Das erste Experiment wurde vor der Nuklearkatastrophe von Fukushima durchgeführt, dass zweite danach. In beiden Experimenten hatten die Teilnehmer die Möglichkeit, von ihrem verfügbaren Einkommen direkt in Klimaschutz zu investieren. Hierzu wurden ihnen $\mathrm{CO}_{2}$-Zertifikate aus dem Europäischen Emissionshandelssystem zum Kauf angeboten. Die von den Teilnehmern gekauften Zertifikate wurden im Anschluss an die Experimente stillgelegt.

Die Nachfrage nach Klimaschutz ist im Experiment nach der Nuklearkatastrophe signifikant höher als im Experiment vor der Katastrophe. Die Ergebnisse lassen den Schluss zu, dass Teilnehmer, die ein bestimmtes Maß an nationalem Klimaschutz garantieren wollen oder die durch die nukleare Katastrophe die Gefahr von klimabedingten Extremwetterereignissen stärker wahrgenommen haben, ihr privates Engagement für Klimaschutz ausgeweitet haben. 
Did Fukushima Matter?

\title{
Empirical Evidence of the Demand for Climate Protection in Germany
}

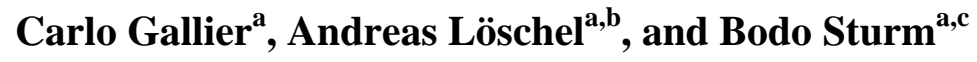 \\ ${ }^{a}$ Centre for European Economic Research (ZEW), Mannheim \\ ${ }^{\mathrm{b}}$ Alfred Weber Institute, University of Heidelberg \\ ${ }^{\mathrm{c}}$ Department of Business Administration, Leipzig University of Applied Sciences
}

Email:

gallier@zew.de

loeschel@zew.de

bodo.sturm@wiwi.htwk-leipzig.de

\begin{abstract}
This paper investigates the extent to which the Fukushima Daiichi nuclear disaster of March 2011 has had an impact on the private demand for climate protection in Germany. Data are taken from two framed field experiments (Löschel et al. 2013a, b) conducted before and after the disaster. We find that the demand for climate protection in the experiment after the nuclear disaster is significantly higher than in the experiment before the disaster.
\end{abstract}

JEL Classification: Q51, Q54, C93

Keywords: Experimental economics, demand for climate protection

Acknowledgement: Support by the Wissenschaftsgemeinschaft Gottfried Wilhelm Leibniz (WGL) and the German Federal Ministry of Education and Research (FKZ 01LA1108B) is gratefully acknowledged. 
"The events in Japan mark a turning point for the world." („Die Geschehnisse in Japan sind ein Einschnitt für die Welt.") German Chancellor Angela Merkel as a reaction to the Fukushima Daiichi nuclear disaster,

March 2011

\section{Introduction}

The aim of this paper is to investigate the extent to which the Fukushima Daiichi nuclear disaster has had an impact on the real private demand for climate protection in Germany.

On March 11, 2011 the Tohoku earthquake and subsequent tsunami hit Japan and the Fukushima Daiichi nuclear power plant. Within a few days, the nuclear power plant went in to melt down and released radioactive material into the air and the ocean (American Nuclear Society 2012). Unsurprisingly, the Fukushima Daiichi nuclear disaster sparked a worldwide discussion about the use of nuclear energy and the security of nuclear power plants. However, why would the Fukushima Daiichi nuclear disaster have an effect on the private demand for climate protection in Germany, being geographically removed and thereby not directly affecting Germany with the radiation emitted? The catastrophe provided the catalyst for a remarkable change in German energy policy which may, in turn, also imply a change in the private willingness to contribute to climate protection. Figure 1 summarises the important events.

In 2002 the German government announced a gradual phase-out of nuclear power plants and the final withdrawal from the use of nuclear power by 2022. However, in October 2010 the German government controversially reversed this decision and announced a lifetime extension for nuclear power plants. Nuclear energy was to be used as a bridging technology for the foreseeable future, whereby, as of 2010, nuclear energy was to be part of the portfolio of carbon free technologies in Germany. On March 11, 2011 the Fukushima Daiichi nuclear disaster demonstrated the risks of nuclear energy, a consequence of which was for the German government to return to the plans of phasing out nuclear power and its partial substitution with fossil fuel-based coal and gas power plants. On March 14, 2011 the German government announced a 3-month moratorium on the lifetime extension. 
Figure 1: German Energy Policy, Fukushima Daiichi Nuclear Disaster and Dates of the

\section{Experiments}

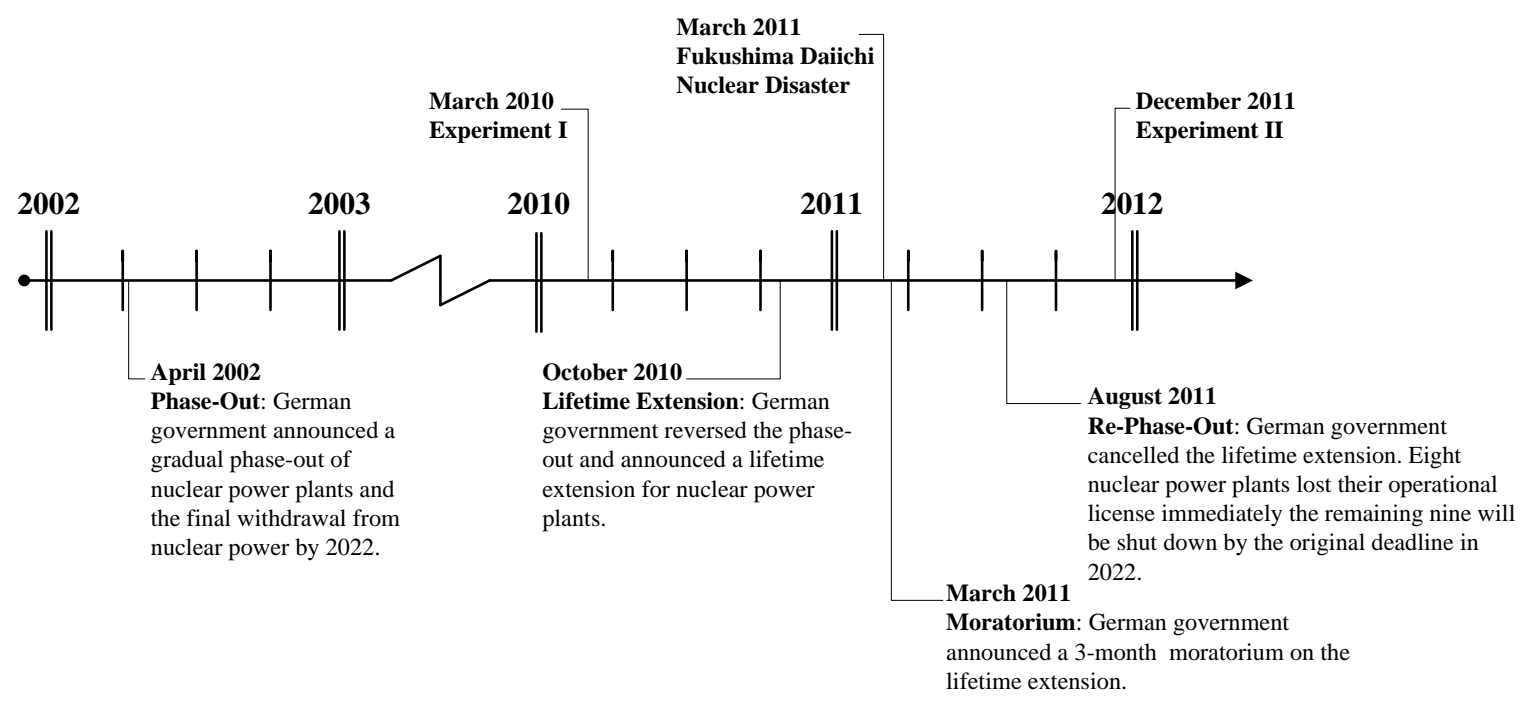

In August 2011 the lifetime extension was cancelled and eight nuclear power plants subsequently lost their operational license, effective immediately. The remaining nine nuclear power plants in Germany will be decommissioned by the original deadline of 2022. This way, the German government has clearly decided to abstain from a carbon free technology. One significant result of this change in German energy policy is the inevitable increase of national $\mathrm{CO}_{2}$ emissions. We argue that people who are unsatisfied with the $\mathrm{CO}_{2}$ emissions related consequences of the change in German energy policy, i.e. the phasing out of carbon free nuclear power and their partial substitution with fossil fuel-based coal and gas power plants, may increase their private contribution to climate protection in order to counteract the increase in national $\mathrm{CO}_{2}$ emission levels. In order to ensure the same national $\mathrm{CO}_{2}$ emissions, the change in German energy policy implies a higher private willingness to contribute to climate protection.

Another argument is that climate change is a potential future driver of nuclear disasters and that the increased awareness of nuclear disasters could therefore influence the willingness to contribute to climate protection. Climate change could be responsible for increasing the likelihood of extreme weather events such as floods, storms, and droughts (e.g., IPCC 2007), which are, in turn, serious threats for nuclear power plants (e.g., International Atomic Energy Agency 2012). Furthermore, climate change could also increase the likelihood of conflicts and nuclear wars (e.g., Scheffran 2009). Therefore, the increased awareness of nuclear disasters, driven by the events in Fukushima may result in the increase in the demand for 
climate protection in order to mitigate climate change and decrease the likelihood of future nuclear disasters.

Data used in this study relating to the demand for climate protection are taken from two framed field experiments (Löschel et al. 2013a, b) conducted in Mannheim, Germany before and after the Fukushima Daiichi disaster. During each of the experiments, subjects were given the opportunity to invest in climate protection from their own disposable income by purchasing and withdrawing permits from the European Emission Trading Scheme (EU ETS). We find that the demand for climate protection in the experiment following the Fukushima Daiichi nuclear disaster is significantly higher than in the experiment before the disaster. Specially, results showed that those participants who were, in principle, willing to invest into climate protection bought significantly more permits in the experiment following the disaster than previously observed.

\section{Experiments}

Both experiments referred to herein took place at the Centre for European Economic Research (ZEW) in Mannheim, Germany and were conducted using participants that had been recruited from the residential population of Mannheim. The first experiment (I) was held in March 2010 and the second experiment (II) in December 2011. In both experiments, an incentive compatible market mechanism was used to elicit participants' real demand for climate protection. Participants received a participation fee of $€ 40$ and were given the opportunity to invest it in climate protection by buying and withdrawing permits from the EU ETS. Each participant was confronted with a set of different prices for permits equating to $100 \mathrm{~kg} \mathrm{CO}_{2}$. Prices ranged from between $€ 0.20$ and $€ 5.00$ per $100 \mathrm{~kg} \mathrm{CO}_{2}$. Thereafter, each participant was asked to indicate the quantity of permits he would be willing to buy at each of the given prices. Finally, one price was randomly selected and the transaction was carried out at the corresponding price. Following the completion of the testing phase, the total quantity of permits were purchased and subsequently withdrawn from the EU ETS. Both experiments were subject to four different treatment variables: baseline, reputation, information, and collective ${ }^{1}$.

\footnotetext{
${ }^{1}$ For a detailed description of the experiments and especially the different treatments see Löschel et al. (2013a, b).
} 
Figure 2: Demand Behaviour

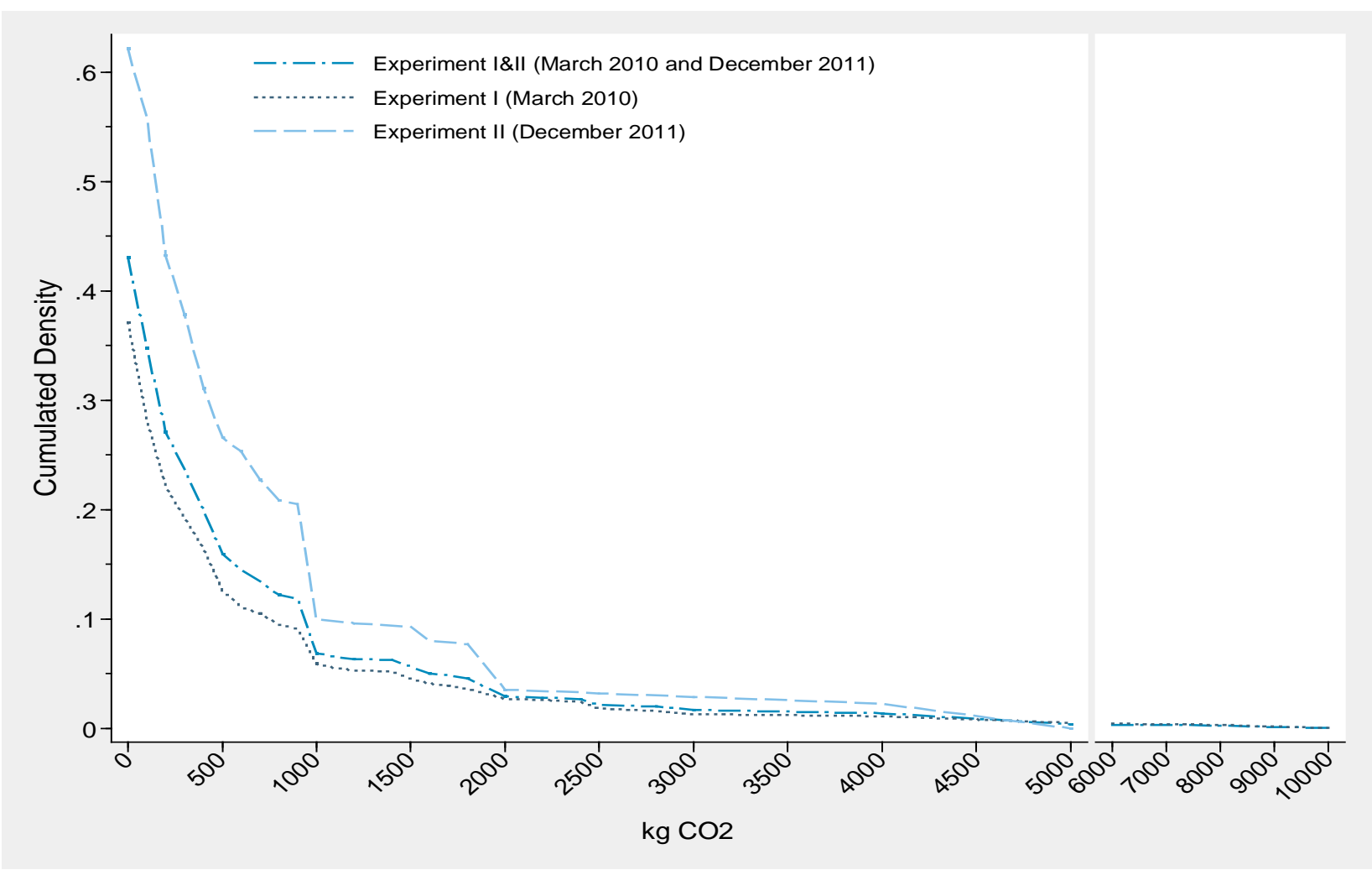

Note:

The horizontal axis represents the purchased amount of $\mathrm{CO}_{2}$ in $\mathrm{kg}$ and the vertical axis the cumulative fraction of participants who are willing to buy an amount greater than the corresponding figure.

\section{Demand for Climate Protection and Pool of Participants}

Participants were recruited following a random distribution of approximately 6,000 letters of invitation in Mannheim, Germany. In total, 360 participants took part, 200 in experiment I and 160 in experiment II. Figure 2 summarises the participants' demand behaviour. In both experiments, the demand for climate protection is characterised by a right skewed distribution. Only in 43 per cent of all observations were participants willing to buy and withdraw permits from the EU ETS. Nevertheless, there is a non-negligible amount of outliers at the right tail of the distribution and the overall demand ranges from $0 \mathrm{~kg}$ to $10,000 \mathrm{~kg} \mathrm{CO}_{2}$ with a median amount of $0 \mathrm{~kg}$ and a mean of approximately $340 \mathrm{~kg} \mathrm{CO}_{2}$. Furthermore, we find that the demand for climate protection increased between experiments I and II. The number of observations in which participants were willing to buy and withdraw permits from the EU ETS increased from 37 per cent before the disaster to 62 per cent after the disaster. 
Consequently, the median amount of purchased permits increased from $0 \mathrm{~kg}$ to $200 \mathrm{~kg} \mathrm{CO}_{2}$ and the mean from approximately $290 \mathrm{~kg}$ to $520 \mathrm{~kg} \mathrm{CO}_{2}{ }^{2}$.

Table 1: Pool of Participants: Socioeconomic Characteristics and Attitudes and Beliefs towards Climate Change

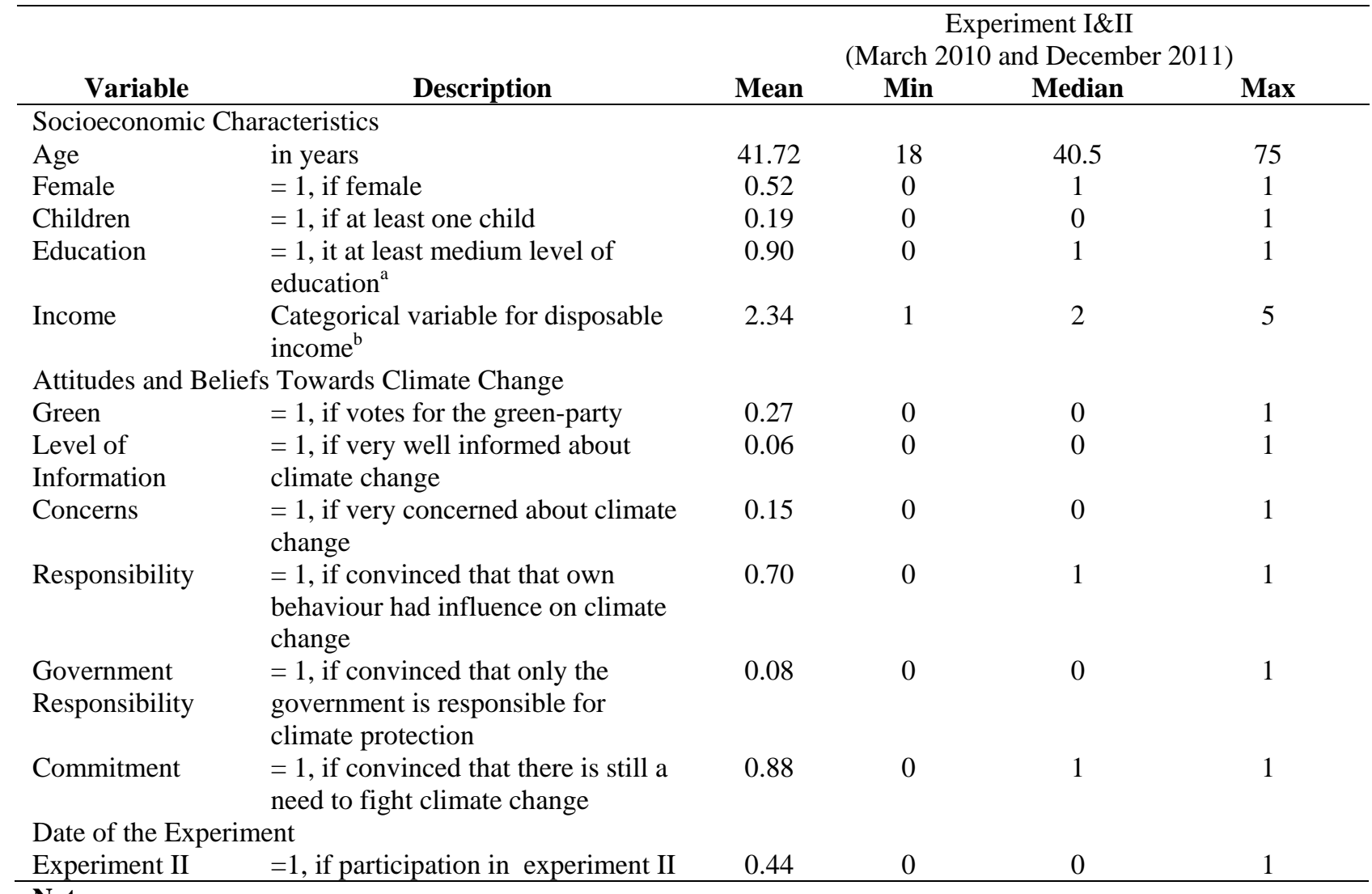

\section{Notes:}

a: Education: 1 (0) have at least a high school graduation or a professional training (others). b: Income: 1 if household income is $\leq 1 \mathrm{k} €$, 2 if $1 \mathrm{k} €<$ income $\leq 2 \mathrm{k} €$, 3 if $2 \mathrm{k} €<$ income $\leq 3 \mathrm{k} €$, 4 if $3 \mathrm{k} €<$ income $\leq 4 \mathrm{k} €, 5$ if $4 \mathrm{k} €<$ income.

Table 1 exhibits participants' socioeconomic characteristics as well as their attitudes and beliefs towards climate protection. Participants' covered all age ranges from 18 to 75 years, whilst the average age of respondents was recorded to be 42 years old. Furthermore, 52 per cent of all participants were female and approximately 20 per cent of all participants stated that children lived in their households. Approximately 90 per cent stated that they had at least a high school certificate or professional training and the households' average income ranged from between €2,000 and €3,000 per month. Furthermore, 27 per cent stated that they would vote for the "green-party" if federal elections were held next Sunday. Nevertheless, only 6 per cent of all participants stated that they are "very well informed" about climate change and

\footnotetext{
${ }^{2}$ According to an Wilcoxon Rank Sum Test, the hypothesis that the demand in both experiments is drawn from the same underlying distribution can be rejected with $p<0.01$.
} 
only 15 per cent that they were "very concerned about climate change”. That said, however, 70 per cent of all participants were convinced that their own behaviour had an influence on climate change and 88 per cent were convinced that there was still a need to fight climate change. Furthermore, only 8 per cent stated that "the government is solely responsible for measures against climate change”. Participants in both experiments did not differ significantly with respect to their socioeconomic characteristics or the majority of their attitudes and beliefs towards climate change. Only the amount of participants who stated that the government is solely responsible for climate protection decreased significantly from 11 per cent in experiment I to 4 per cent in experiment $\mathrm{II}^{3}$.

\section{Econometric Methodology}

The econometric difficulty of our aim, to test the extent to which the Fukushima Daiichi nuclear disaster has had an effect on the demand for climate protection, lies in the distribution of the demand for climate protection; Q. Q is zero in a nontrivial fraction of observations and the remaining observations are roughly continuously distributed about strictly positive values. Therefore, a two-step estimation procedure, as suggested by Heckman (1979), is used. It is based on two decisions: a participation and an amount decision.

$$
\begin{gathered}
(*) \operatorname{Prob}[Q>0 \mid \boldsymbol{w}]=\phi\left(\boldsymbol{w}^{\prime} \boldsymbol{\gamma}\right) \\
(* *) E[Q \mid Q>0, \boldsymbol{x}, \boldsymbol{w}]=\boldsymbol{x}^{\prime} \boldsymbol{\beta}+\rho \lambda\left(\boldsymbol{w}^{\prime} \boldsymbol{\gamma}\right)
\end{gathered}
$$

The participation decision is given by (*) and estimates the binary decision of whether or not participants are willing to buy and withdraw permits from the EU ETS. The amount decision, given by equation $(* *)$ estimates the decision of how many permits to buy and withdraw given that demand is strictly positive. Furthermore, the unobserved correlation between both decisions is given by $\rho$. Note that a simple OLS regression of only strict positive observations on a set of independent variables in the amount decision would lead to inconsistent estimators if there is any unobserved correlation between the participation and amount decision. In order to avoid inconsistent estimates in the amount decision, the inverse Mills ratio has to be estimated based on the results of the participation decision and be included as an additional independent variable in the amount decision. The inverse Mills ratio is given by $\lambda(\cdot)=\frac{\phi(\cdot)}{\Phi(\cdot)}$, where $\phi(\cdot)$ and $\Phi(\cdot)$ are the density and cumulative distribution function of a standard normal

\footnotetext{
${ }^{3}$ All comparisons concerning the differences between the participants in both experiments are based on $\chi_{2}$-Tests with $p<0.05$.
} 
distributed random variable (e.g., Green 2003). Finally, we derived a set of price-quantity observations for each participant. Therefore, in all regression models a panel specification with random effects on subject level is used and clustered standard errors are allowed for.

\section{Results}

Table 2 summarises our main results. Model (1) contains the results of the binary participation decision. In order to allow for an appropriate interpretation, the average marginal effect (AME) is calculated in addition to the regression coefficients. Model (2) contains the amount decision ${ }^{4}$.

Since the null hypothesis that there is any unobserved correlation between the participation and the amount decision (that $\rho$ is equal zero) cannot be rejected, it seems to be plausible to estimate the amount decision by means of an OLS regression of the quantity demanded on the independent variables, given that the demand is strictly positive (e.g., Wooldridge 2006). These results are given in model (3). After controlling for participants' demographic and socioeconomic characteristics as well as their attitudes and beliefs towards climate change and the different treatments we find that the timing of the experiments (Experiment II) had a significant impact on the demand for climate protection. The demand for climate protection is significantly higher in experiment II than in experiment I. Given that the demand is strictly positive, the demand increased in experiment II by approximately 40 per cent.

Moreover, whilst the timing of the experiment clearly influenced demand behaviour, so too did the price of the permits, participants' demographic and socioeconomic characteristics, and attitudes and beliefs towards climate change. The price of permits has a significantly negative impact on the demand of climate protection. Given that the demand is strictly positive, the price elasticity of demand is estimated to be approximately -1 . Furthermore, participants' socioeconomic characteristics such as their age and disposable income influence the demand for climate protection. Demand decreases with age and increases with disposable income. Participants' attitudes and beliefs towards climate change also influence their demand. Participants who are concerned about climate change, feel responsible for it, and are convinced that there is still a need to fight climate change, have a significantly higher demand.

\footnotetext{
4 According to the exclusion restriction (e.g., Wooldridge 2006), we excluded the independent variable Responsibility from the amount decision in order to reduce multicollinearity in model (2).
} 


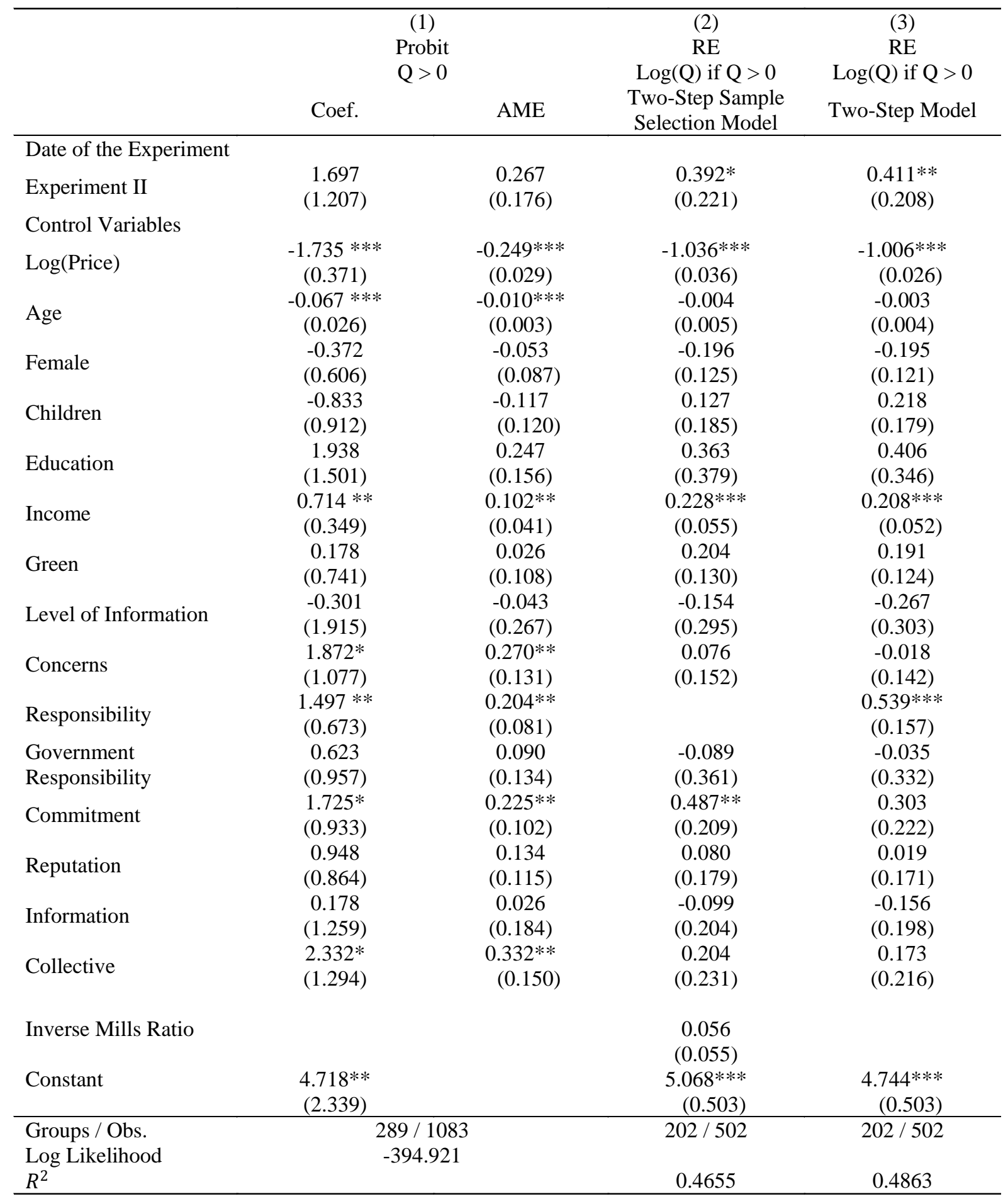

Notes: (i) *,**, *** indicates significance at the 10\%, 5\% and 1\% level. Standard errors in parentheses.

(ii) Definition of variables: Q: quantity kg demanded; Experiment II: 1 (0) if participation in experiment II (experiment I); Log(Price): natural log of price in €Cent; Age: age in years; Female: 1 (0) if female (male); Children: 1 (0) if at least on child (no children); Education: 1 (0) have at least a high school graduation or a professional training (others); Income: 1 if household income is $\leq 1 \mathrm{k} €, 2$ if $1 \mathrm{k} €<$ income $\leq 2 \mathrm{k} €, 3$ if $2 \mathrm{k} €<$ income $\leq 3 \mathrm{k} €, 4$ if $3 \mathrm{k} €<$ income $\leq 4 \mathrm{k} €$, 5 if $4 \mathrm{k} €<$ income; Green: 1 (0) if green voter (other); Level of Information: $1(0)$ if information about climate change is very good (other) ; Concerns: 1 (0) if concerns about climate change are very strong (other); Responsibility: 1 (0) if convinced that own behaviour had influence on climate change (other); Government Responsible: $1(0)$ if convinced that only the government is responsible for climate protection (other); Commitment: $1(0)$ if convinced that there is still a need to fight climate change (other); Reputation: 1 (0) if treatment reputation (other); Information: 1 (0) if treatment information; Collective: 1 (0) if treatment collective (other). 


\section{Conclusion}

This paper finds that the individual demand for climate protection among a sample of the residential population of Mannheim, Germany has changed significantly between March 2010 and December 2011. There is evidence that the Fukushima Daiichi nuclear disaster of March 2011 increased the demand for climate protection. One reason for the increase in private demand for climate protection may be the move to decommission nuclear power and the remarkable change in the German energy policy as a reaction to the Fukushima Daiichi nuclear disaster. Individuals who want to guarantee a certain level of climate protection increased their private willingness to contribute to climate protection in order to counteract the increase in national emissions due to the nuclear phase-out in Germany. This is consistent with the finding that the amount of participants who were convinced that the government is solely responsible for climate protection decreased significantly by 7 per cent between the two experiments. Another possibility is that the increased awareness of nuclear disasters raised the private willingness to contribute to climate protection in order to mitigate climate change and decrease the likelihood of future nuclear disasters caused by extreme weather events.

\section{References}

American Nuclear Society (2012). Fukushima Daiichi: ANS Committee Report. http://fukushima.ans.org/report/Fukushima_report.pdf

Green, W. (2003). Econometric Analysis. Fifth Edition Pearson Education International.

Heckman, J. (1979). Sample Selection Bias as a Specification Error. Econometrica 47 (1), 153-161.

International Atomic Energy Agency (2012). Communication dated 24 August 2012 from the Chairman of the International Nuclear Safety Group (INSAG). http://www.iaea.org/About/Policy/GC/GC56/GC56InfDocuments/English/gc56inf-11_en.pdf Intergovernmental Panel on Climate Change (2007). Climate Change 2007: Impacts, Adaptation and Vulnerability. Contribution of Working Group II to the Fourth Assessment Report of the Intergovernmental Panel on Climate Change. http://www.ipcc.ch/pdf/assessment-report/ar4/wg2/ar4_wg2_full_report.pdf

Löschel, A., B. Sturm and C. Vogt (2013a). The Demand for Climate Protection - Empirical Evidence from Germany. Economics Letters 118 (3), 415-418. 
Löschel, A., B. Sturm and R. Uehleke (2013b). Revealed Preferences for Climate Protection when the Purely Individual Perspective is Relaxed - Evidence from a Framed Field Experiment. ZEW Discussion Paper No. 13-006, Mannheim.

Scheffran, J. (2008). Climate Change and Security. Bulletin of the Atomic Scientists 64 (2), $19-25$.

Wooldridge, J. (2006). Introductory Econometrics. A Modern Approach. Third Edition Thomson Higher Education. 